\title{
Effect of probiotic acidophilus plus against infection with secondary hydatid disease in BALB /c mice
}

\author{
S.Y. Yousif ${ }^{1}$ and A.A. Ali ${ }^{2}$ \\ Department of Biology, College of Education for Pure Sciences, University of Mosul, Mosul, Iraq \\ Email: ${ }^{1}$ massd2313@gmail.com, ${ }^{2}$ assssali@uomosul.edu.iq
}

(Received April 7, 2019; Accepted May 19, 2019)

\begin{abstract}
The current study investigated the effect of acidophilus plus probiotic in the immune activities in mice to infestation with the cystic echinococcosis. Two dilutions of the probiotic bacteria $9^{*} 10^{6} / 0.1 \mathrm{ml}, 30^{*} 10^{3} / 0.1 \mathrm{ml}$ CFU were used, by intraperitoneally injection in the experimental animals, pre and post infections with protoscoleces of Echinococcus granulosus. Before infection remedy comprised injection by acidophilus plus twice with 72 hours interval, on the seventh day, animals were injected with protoscoleces intraperitoneally, after infection remedy implicated injection of animals with protoscoleces of Echinococcus protoscoleces first, next to 72 hours, probiotics were inoculated intraperitoneally. Many criteria were taken into consideration including, numbers, weights, diameters and percentage reduction of hydatid cysts of treated mice in contrast to the animals infested with only. The study showed a decline in cysts including their diameter, weighting, digit, accompanied by increasing the percentage reduction of hydatid cysts in treated mice, the highest percentage reduction was $98.03 \%$, at both dilutions, 6 months post infection, and the minimum cysts number was 0.8 in comparison with the control group 39.4, with significant difference, in the same experiment. The minimum cysts weight was $0.0104 \mathrm{gm}, 6$ months post infection at the dilution $9 * 10^{6} / 0.1 \mathrm{ml} \mathrm{CFU}$, compared with the control group $0.442 \mathrm{gm}$. The smallest cysts diameter was $0.057 \mathrm{~mm}$ in comparison with the control group $0.882 \mathrm{~mm}$ at dilution $9^{*} 10^{6} / 0.1 \mathrm{ml} \mathrm{CFU,} 6$ months post infection. Acidophilus plus it may well be deduced that probiotic bacteria can be used as medicinal and remedial method against infection with hydatidosis.
\end{abstract}

Keywords: Probiotics, Lactobacillus acidophilus, L. casei casei, L. casei rhamnosus, Hydatid disease Available online at http://www.vetmedmosul.com, (C) 2020, College of Veterinary Medicine, University of Mosul. This is an open access article under the CC BY 4.0 license (http://creativecommons.org/licenses/by/4.0/).

\section{تأثير المعزز الحيوي acidophilus plus ضد الإصابة بداء الأكياس العدرية الثانوي في الفئران سهيلة يعقوب يوسف و أسماء عبدالعزيز علي فرع علوم الحياة، كلية التربية للعلوم الصرفة، جامعة الموصل، الموصل، العراق}

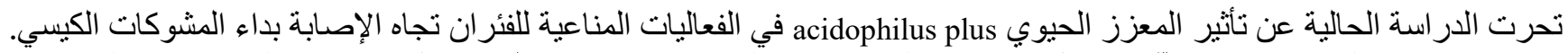

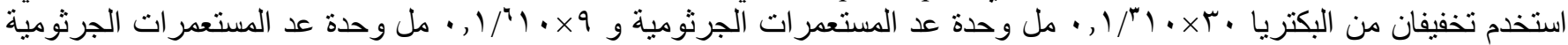

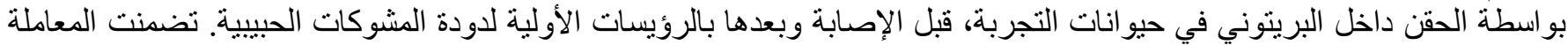

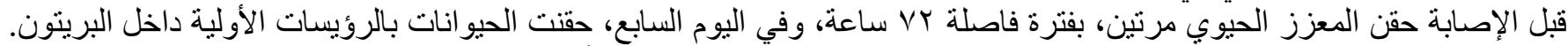

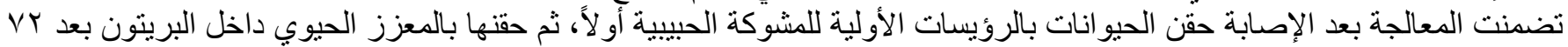

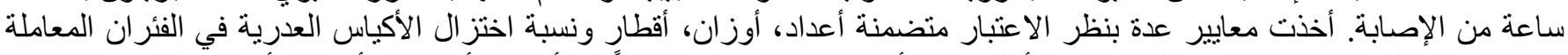

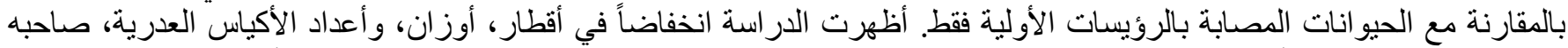

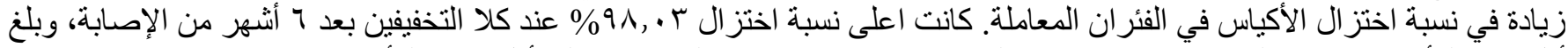

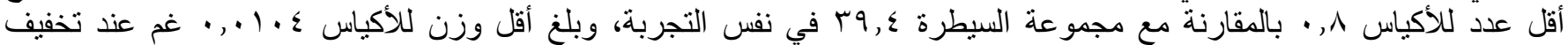




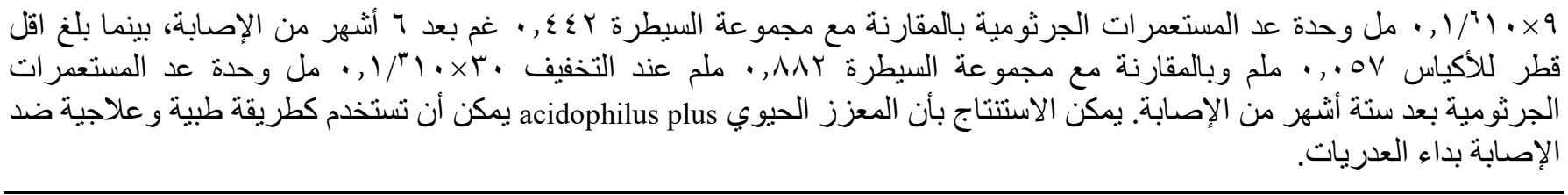

\section{Introduction}

Cystic echinococcosis is the larval cystic stage (called Echinococcal cysts) of a small taeniid-type tapeworm (Echinococcus granulosus) that may cause illness in intermediate hosts, generally herbivorous animals and people who are infected accidentally, it a zoonotic disease spreads worldwide, a common prevalent in stock raising areas, like Australia and Middle East region (1). It is neglected tropical areas disease, which is the most important reason of health deficiency and economic losses. China is account as a considerable part of the global loss (2). Cystic echinococcosis is causing by Echinococcus cestoda, the common species, E. granulosus. Humans are accidentally infected by ingesting the parasite eggs which are raised from specific hosts (e.g. wolves, dogs, foxes, and jakals) (3), by fecal-oral stream. Parasite ova ingested in the human digestive systems, hatched in duodenum, growing up as larvae and passing through the gut wall into liver with blood route. About $75 \%$ of cases affect liver $(2,4,5)$. The taxonomy of genotypes/species, leading to cystic echinococcosis, includes the subdivided E. garnulosus senso lato complex groups, E. granulosus sensu srtricto, E. equines, E. ortleppi, E. Canadensis, and E. felids (lion strain) $(6,7)$. In medicine, it is difficulty for drugs to permeate into the multiple layers of the hydatid cyst, but chemotherapy and operation are still the most utilized methods for therapy of cystic Echinococcosis (8). Albendazole drug is ovicidal, larvicidal and vermicidal, but operation is still the main treatment $(3,9)$. So, researchers, in recent years, have developed new alternatives in an attempt for elimination of some parasitic infections. The most important is the use of probiotic bacteria, probiotics represent microbiota of different sources endogenous and exogenous, of which are most important for human and animals if administrated on adequate amount (10). The prophylactic activity of this type of bacteria may be by competition, seclusion and impedance to harmful bacteria of the intestine. Other technique involves synthesis of compounds against bacteria, includes $\mathrm{H}_{2} \mathrm{O}_{2}$, bacteriocin, and immunomodulation (11). Several studies proved the efficacy of probiotics for prevention against many diseases such as, cancer, allergies, inflammatory, intestinal and autoimmune disease (12). Probiotics effect on other eukaryotic pathogens, explained the efficacy of Lactobacillus in the prevention contra extra intestinal parasites, such as Plasmodium, Babesia (13). The effects of useful microorganisms, probiotics became interesting for their protection or therapeutic applications against diseases including worm diseases (14) like zoonotic Schistosomiasis which is caused by genus Schistosoma (15). Other probiotics strains such as L. acidophilus, L. plantarum and $L$. delbrueckii revealed an obvious activity versus ancylostomiasis in normally affected canine with a disease. Elevation of white blood cells has been observed (16). Researchers found that $L$. casei is the firstly strain among other strains of Lactobacilli has anthelmintic effect of about $75-100 \%$ prevention, another strain is L. plantarum with efficacy of $90 \%$ against Trichenilla spiralis (17).

The aim of the current study is to use probiotic bacteria, for the first time, against infection with secondary hydatid disease as an antiparasitic immunomodulator in BALB/c mice, depending on many criteria including numbers, weights, diameters, and percentage reduction of hydatid cysts in the experimental animals, in comparison with the control group.

\section{Material and methods}

\section{Laboratory animals}

One month-aged experimental animals (Swiss mice) were utilized.

\section{Cysts samples}

Ovine cysts containing protoscoleces were obtained under sterilized conditions, alive protoscoleces, $20 \mu \mathrm{l}$ of protoscoleces suspension were added to $20 \mu \mathrm{l}$ of $0.1 \%$ of eosin pigment on a slid, then tested under light microscope. Bright green protoscoleces were considered as alive because of eosin exclusion by protoscoleces membranes, whereas red protoscoleces were regarded as dead because of acceptance of the pigment gained and counted according to authenticated manner $(18,19,20)$.

\section{Bacterial strains preparation and inoculation}

One capsule of acidophilus plus provides lactobacilli culture, typically providing 2 billion of $L$. acidophilus, $L$. casei casei and L. casei rhamnosus. These lactobacilli strains were grown in nutrient broth medium for 24 hours then the culture was diluted in normal saline to contain $9 * 10^{6} / 0.1 \mathrm{ml}$ CFU of acidophilus plus probiotics, the second dilution in normal saline contains $30^{*} 10^{3} / 0.1 \mathrm{ml}$ CFU of acidophilus plus probiotics $(16,20)$. 


\section{Experimental design}

Animals were divided into seven groups, each group comprised of five animals. Group one: 30 Mice (5 mice for each experiment as control group) were injected with 2000 protoscoleces $/ 20$ gm body weight intraperitoneally by 0.1 $\mathrm{ml}$ of protoscoleces diluted in phosphate buffer saline (PBS). Group two: 5 Mice were injected intraperitoneally with the probiotic acidophilus plus $9 * 10^{6} / 0.1 \mathrm{ml}$ CFU, twice with interval 72 hours, on the $7^{\text {th }}$ day mice were injected with 2000 protoscoleces. Injection with probiotics continued for 50 days. Mice were dissected 2 months post infection. Group three: 5 Mice were injected intraperitoneally with probiotic acidophilus plus $9 * 10^{6} / 0.1$ $\mathrm{ml} \mathrm{CFU,} \mathrm{twice} \mathrm{with} \mathrm{interval} 72$ hours, on the $7^{\text {th }}$ day mice were injected with 2000 protoscoleces intraperitoneally. Injection with probiotics continued for 110 days. Mice were dissected 4 months post infection. Group four: 5 Mice were injected intraperitoneally with probiotic acidophilus plus $9 * 10^{6 /} / 0.1 \mathrm{ml} \mathrm{CFU}$, for 170 days with 72 hours intervals, on the $7^{\text {th }}$ day mice were injected with 2000 protoscoleces intraperitoneally. Mice were dissected 6 months post infection. Group five: 5 Mice were injected intraperitoneally with 2000 protoscoleces, after 3 days the mice were injected intraperitoneally with acidophilus plus $30^{*} 10^{3} / 0.1 \mathrm{ml} \mathrm{CFU}$ for 50 days, with 72 hours intervals, mice were dissected after 2 months. Group six: 5 Mice were injected intraperitoneally with 2000 protoscoleces, after 3 days mice were injected intraretinally with acidophilus plus $30^{*} 10^{3} / 0.1 \mathrm{ml} \mathrm{CFU}$ for 110 days with 72 hours intervals, mice were dissected after 4 months. Group seven: 5 Mice were injected intraperitoneally with 2000 protoscoleces, after three days mice were injected with acidophilus plus $30^{*} 10^{3} / 0.1 \mathrm{ml} \mathrm{CFU}$ for 170 days with 72 hours intervals, mice were dissected after 6 months.

\section{Statistical analysis}

For testing the variances between the periods and dilution of bacteria acidophilus plus, a Complete Randomized Design (CRD) was performed. Then, the variances between group's mean values were tested by Duncan's multiple range test. The test periods, as a quantitively value, were compared by the Analysis of Variance (ANOVA). Two ready packages, Statistical Analysis System (SAS) and Minitab were applied (21).

\section{Results}

Cysts weights declined obviously in groups cured with acidophilus plus, reached the minimum $0.0104 \mathrm{gm}$ at the dilution $9 * 10^{6} / 0.1 \mathrm{ml}(\mathrm{CFU})$ after 6 months of infestation, opposed infected animals with the parasite only $0.442 \mathrm{gm}$ (Table 1, Table 5).
Table 1: Impact of acidophilus plus $9 * 10^{6} / 0.1 \mathrm{ml}, 30 * 10^{3}$ $10.1 \mathrm{ml}$ (CFU) on means of larval stages weights for animals infested with in contrast to the untreated set after 2, 4, 6 months

\begin{tabular}{lcccc}
\hline $\begin{array}{l}\text { Dilution of } \\
\text { bacteria }\end{array}$ & $\begin{array}{c}\text { Two } \\
(\mathrm{gm})\end{array}$ & $\begin{array}{c}\text { Four } \\
(\mathrm{gm})\end{array}$ & $\begin{array}{c}\text { Six } \\
(\mathrm{gm})\end{array}$ & $\begin{array}{c}\text { Means of } \\
\text { bacterial } \\
\text { treatment }\end{array}$ \\
\hline $10^{6}$ & $0.0197^{\mathrm{b}}$ & $0.0123^{\mathrm{b}}$ & $0.0104^{\mathrm{b}}$ & $0.0284^{\mathrm{b}}$ \\
$10^{3}$ & $0.00419^{\mathrm{b}}$ & $0.037^{\mathrm{b}}$ & $0.0144^{\mathrm{b}}$ & $0.018^{\mathrm{b}}$ \\
Control & $0.0626^{\mathrm{b}}$ & $0.316^{\mathrm{a}}$ & $0.442^{\mathrm{a}}$ & $0.273^{\mathrm{a}}$ \\
\hline Mean Periods & $0.0288^{\mathrm{b}}$ & $0.1217^{\mathrm{a}}$ & $0.1558^{\mathrm{a}}$ & 0.1016 \\
\hline
\end{tabular}

Similar letters indicate no significant differences, while different letters indicate significant differences.

Cysts numbers minimized meaningfully among all treated albino animals by acidophilus plus, reached the minimum 0.8 cyst at the dilutions $9^{*} 10^{6} / 0.1 \mathrm{ml}$ and $30 * 10^{3} / 0.1 \mathrm{ml}$ (CFU) 6 months post infection in comparison with the control group 39.4 cyst (Table 2, Table 5, Figures 1-3).

Table 2: Effect of acidophilus plus $9 * 10^{6} / 0.1 \mathrm{ml}$ and $30^{*} 10^{3} / 0.1 \mathrm{ml}(\mathrm{CFU})$ on means of larval stages numbers of treated animals affected of the disease opposed the unprocessed collection through 2, 4, 6 months

\begin{tabular}{|c|c|c|c|c|}
\hline \multirow{2}{*}{$\begin{array}{l}\text { Dilution of } \\
\text { bacteria }\end{array}$} & \multicolumn{3}{|c|}{ Months } & \multirow{2}{*}{$\begin{array}{l}\text { Means of } \\
\text { bacterial } \\
\text { treatment }\end{array}$} \\
\hline & $\begin{array}{l}\text { Two } \\
\text { (gm) }\end{array}$ & $\begin{array}{l}\text { Four } \\
(\mathrm{gm})\end{array}$ & $\begin{array}{l}\text { Six } \\
(\mathrm{gm})\end{array}$ & \\
\hline $10^{6}$ & $2.6^{\mathrm{cb}}$ & $1.4^{\mathrm{c}}$ & $0.8^{c}$ & $1.60^{\mathrm{b}}$ \\
\hline $10^{3}$ & $3.6^{\mathrm{cb}}$ & $1.6^{\mathrm{c}}$ & $0.8^{\mathrm{c}}$ & $2.00^{\mathrm{b}}$ \\
\hline Control & $6.6^{\mathrm{cb}}$ & $8.2^{\mathrm{b}}$ & $39.4^{\mathrm{a}}$ & $18.06^{\mathrm{a}}$ \\
\hline Mean Periods & $4.3^{\mathrm{b}}$ & $3.73^{\mathrm{b}}$ & $13.6^{\mathrm{a}}$ & 6.90 \\
\hline
\end{tabular}

Similar letters indicate no significant differences, while different letters indicate significant differences.

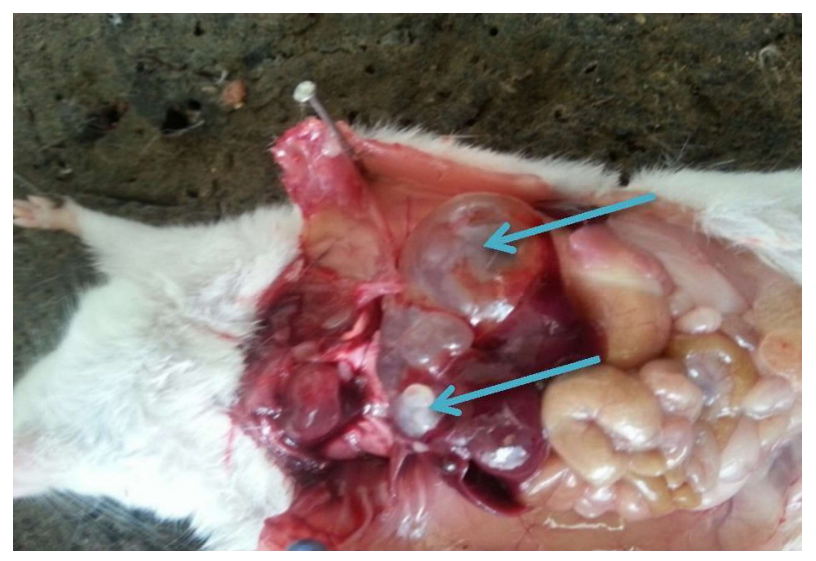

Figure 1: Mouse infected with protoscoleces 4 months postinfection (control). 


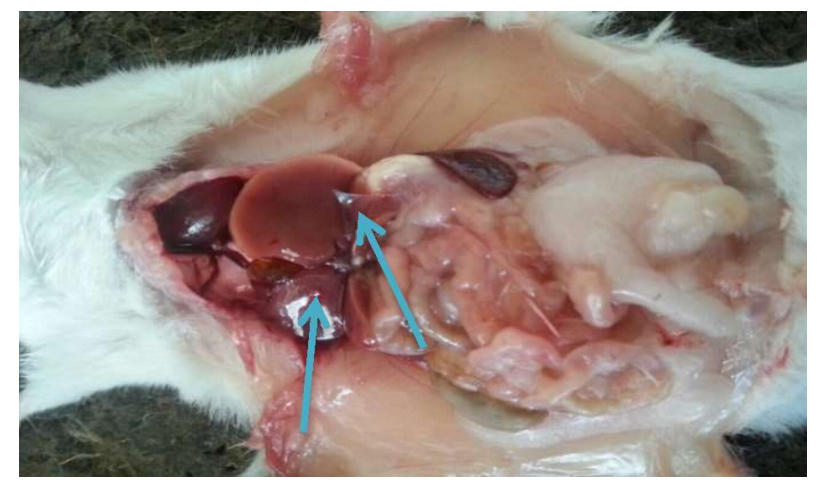

Figure 2: Mouse infected with protoscoleces treated by acidohilus plus $30 * 103 / 0.1 \mathrm{ml}$ (CFU) 4 months postinfection.

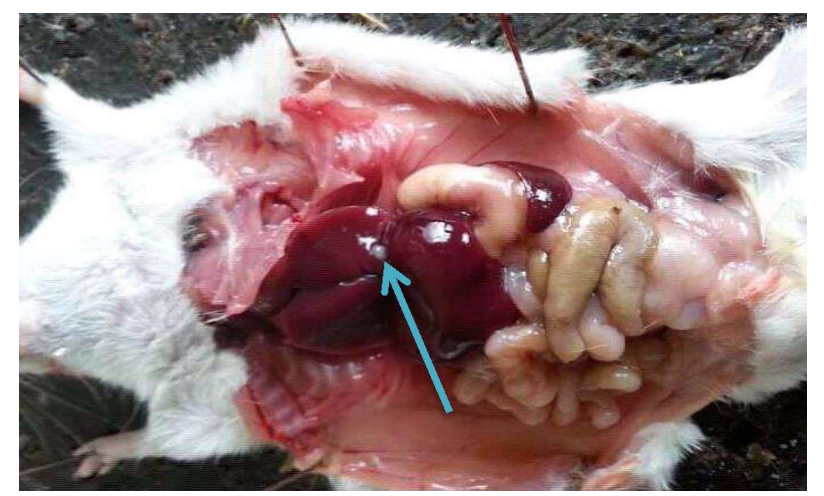

Figure 3: Mouse infected with protoscoleces treated by acidohilus plus $9 * 10^{6} / 0.1 \mathrm{ml}$ (CFU)- 4 months post infection.

Cysts diameters diminished clearly in all handled animals by acidophilus plus, reached the minimum 0.057 $\mathrm{mm}$ at the dilution $9 * 10^{6} / 0.1 \mathrm{ml}(\mathrm{CFU})$ after 6 months of invasion compared to uncured association $0.882 \mathrm{~mm}$ (Table 3 , Table 5, Figures 4 and 5).

Table 3: Effect of acidophilus plus $9 * 10^{6} / 0.1 \mathrm{ml}$ and $30^{*} 10^{3} / 0.1 \mathrm{ml}$ (CFU) on means of cystic larvae diameters of treated animals occupied by protoscoleces rapprochement to the versus groups during 2, 4, 6 months

\begin{tabular}{|c|c|c|c|c|}
\hline \multirow[b]{2}{*}{$\begin{array}{l}\text { Dilution of } \\
\text { bacteria }\end{array}$} & \multicolumn{3}{|c|}{ Months } & \multirow{2}{*}{$\begin{array}{l}\text { Means of } \\
\text { bacterial } \\
\text { treatment }\end{array}$} \\
\hline & $\begin{array}{l}\text { Two } \\
\text { (mm) }\end{array}$ & $\begin{array}{l}\text { Four } \\
(\mathrm{mm})\end{array}$ & $\begin{array}{c}\text { Six } \\
(\mathrm{mm})\end{array}$ & \\
\hline $10^{6}$ & $0.375^{\mathrm{cb}}$ & $0.106^{\text {cd }}$ & $0.057^{\mathrm{d}}$ & $0.179^{\mathrm{b}}$ \\
\hline $10^{3}$ & $0.089^{\mathrm{cb}}$ & $0.131^{\mathrm{cd}}$ & $0.071^{\mathrm{d}}$ & $0.097^{b}$ \\
\hline Control & $0.497^{b}$ & $0.500^{\mathrm{b}}$ & $0.882^{\mathrm{a}}$ & $0.794^{\mathrm{a}}$ \\
\hline Mean Periods & $0.320^{\text {ba }}$ & $0.245^{\mathrm{b}}$ & $0.336^{\mathrm{a}}$ & 0.432 \\
\hline
\end{tabular}

Similar letters indicate no significant differences, while different letters indicate significant differences.
Table 4: Effect of acidophilus plus $9 * 10^{6} / 0.1 \mathrm{ml}$ and $30^{*} 10^{3} / 0.1 \mathrm{ml}(\mathrm{CFU})$ on lowering proportion in larvae cysts of the treated occupied association with the parasite parallel to the surveillance animals within 2, 4, 6 months

\begin{tabular}{lcccc}
\hline Treatment & Months & $\begin{array}{c}\text { Mice } \\
\text { No. }\end{array}$ & $\begin{array}{c}\text { Hydatid } \\
\text { cysts treated }\end{array}$ & $\begin{array}{c}\text { Reduction } \\
\%\end{array}$ \\
\hline $10^{6}$ & 2 & 5 & $2.6^{\mathrm{cb}}$ & 60 \\
$10^{3}$ & 2 & 5 & $3.6^{\mathrm{cb}}$ & 45 \\
Control & 2 & 5 & $6.6^{\mathrm{cb}}$ & \\
$10^{6}$ & 4 & 5 & $1.4^{\mathrm{c}}$ & 82.9 \\
$10^{3}$ & 4 & 5 & $1.6 \mathrm{c}$ & 80.5 \\
Control & 4 & 5 & $8.2^{\mathrm{b}}$ & \\
$10^{6}$ & 6 & 5 & $0.8^{\mathrm{c}}$ & 98.03 \\
$10^{3}$ & 6 & 5 & $0.8^{\mathrm{c}}$ & 98.03 \\
Control & 6 & 5 & $39.4^{\mathrm{a}}$ & \\
\hline
\end{tabular}

Similar letters indicate no significant differences, while different letters indicate significant differences.

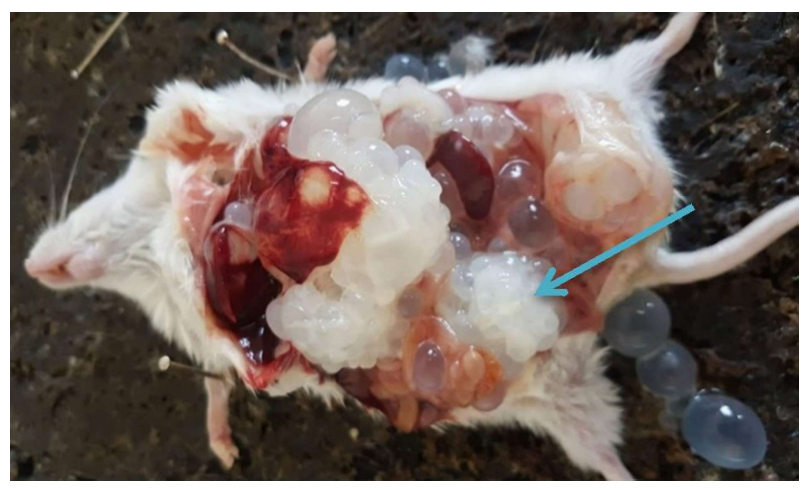

Figure 4: Mouse infected with protoscoleces 6 months postinfection (control).

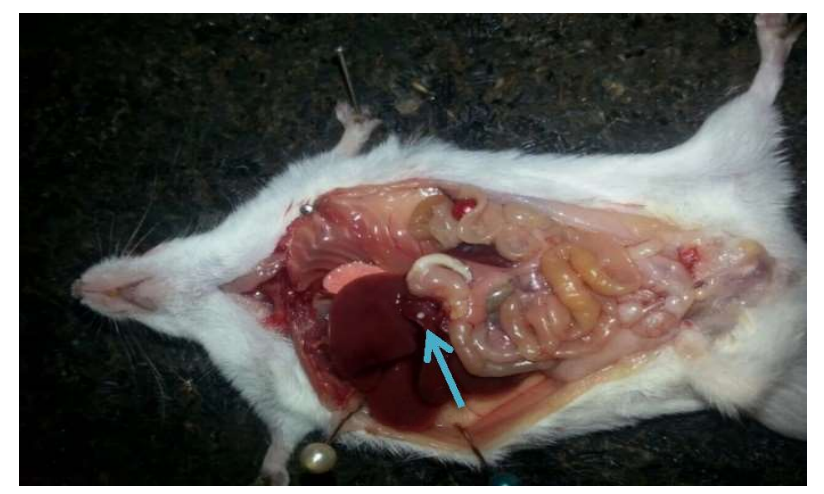

Figure 5: Mouse infected with protoscoleces and treated by acidophilus $9 * 10^{6} / 0.1 \mathrm{ml}$ (CFU) 6 months.

The percentage reduction decreased in all treated mice, reached the maximum $98.03 \%$ at the dilution $9 * 10^{6} / 0.1 \mathrm{ml}$ and $30^{*} 10^{3} / 0.1 \mathrm{ml}(\mathrm{CFU})$ post infection 6 months (Table 4 ). 
Table 5: ANOVA analysis explain the effect of acidophilus plus dilutions $9 * 10^{6} / 0.1 \mathrm{ml}$ and $30^{*} 10^{3} / 0.1 \mathrm{ml}(\mathrm{CFU})$ on weights, Diameters, numbers means of larval stages of invaded band with the differentiated with the monitoring set

\begin{tabular}{lcccccc}
\hline Treatment & Animals No. & $d f$ & Weight $(\mathrm{gm})$ & Cysts No. & Cyst Wt. $(\mathrm{gm})$ & Cyst diameter $(\mathrm{mm})$ \\
\hline Bacteria & 5 & 2 & $68.00^{* *}$ & $1176.1^{* *}$ & $0.115^{*}$ & $1.157^{*}$ \\
$10^{6}, 10^{3}$ verse control & 5 & 1 & $107.80^{* *}$ & $2351.1^{* *}$ & $0.219^{* *}$ & $2.289^{* *}$ \\
Durations & 5 & 2 & $327.18^{* *}$ & $382.4^{* *}$ & 0.068 & 0.6117 \\
Linear & 5 & 1 & $584.32^{* *}$ & $537.0^{* *}$ & $0.137^{*}$ & 0.4222 \\
Square & 5 & 1 & $70.04^{*}$ & $227.2^{*}$ & 0.00007 & 0.8013 \\
Bacteria in periods & 5 & 4 & $41.46^{*}$ & $528.2^{* *}$ & 0.0429 & 0.2712 \\
Empirical error & 5 & 36 & 8.06 & 34.7 & 0.03 & 0.306 \\
\hline
\end{tabular}

* refers to significant at $5 \%, * *$ refers to Significant at $1 \%, d f$ mean degree of freedom.

\section{Discussion}

In the recent years, the efficiency of useful probiotics to the body rely on the mechanization, through which they do their action by numerous processes implicating manufacture of microbe killer materials, modification the mucosa of the defense order, exchange gut microflora, boosting action of enzymes (22). Both dilution of bacteria probiotic (pre and post infection) exhibited significant effect on the infection in treated animals in comparison with the control group, and the effect is directly fit with period of treatment because treatment with bacteria continued nearly all the period of infection $(2,6,8)$ months, respectively. In general, pre-infection treatment with bacteria $9 * 10^{6} / 0.1 \mathrm{ml}(\mathrm{CFU})$ was stronger in effect that post infection treatment, this due to the stimulation of immune response of the treated experimental animals. Present study revealed antiparasitic effect of probiotic acidophilus plus (for both dilution), explained by significant decrease, of larval stage digit, weightiness, diameter, in addition increase in reduction proportion in hydatid cysts through the experiments period.

The primary route of bacterial activity to parasitic hitting possibly through boosting gut hurdle (23-26). Helpful bacteria could also increase useful microbiota numbering as lactobacillus, that suppress harmful bacteria development via contesting on connection region on the gut endothelial layer. Another mechanics might imply excretion of some micro killer materials, mostly produced from lactic acid bacteria and could be hold potency against parasitic larvae (27). Moreover, bacterial output holds anthelmintic influence that might decrease maliciousness of numerous protozoa and helminthic illness (28). These results are similar to the study of Mohamed et al (29) and Zowail et al (30) who proved the protective and curative effects of useful bacteria in mice models against infection of Schistosoma mansoni (29-31). Many strains of probiotics, like Zymomonas mobilis $1 * 10^{9} \mathrm{CFU} / \mathrm{ml}$, when administrated by mouth provoked minor defense reaction, in mice against $S$. mansoni by providing prevention in treated animals $(31,32)$. When Lactobacillus sporogenes used orally at a certain dose, for a long time,since the beginning of the infestation with $S$. mansoni, minimized impairment of DNA, improves liver and gut deterioration, therefore weakened adult together with ova numbers (29).

Results of the present study are also consistent with the Bsualdo et al (33) who assessed the protection effects of probiotic bacteria versus Toxocariasis within experimental animals. They provoked considerable shorthand in worm number in empirical animals processed with Enterococcus faecalis, further, E. faecalis in variable dosage revealed effect against larvae outside and inside the body (25). Likewise, another study on Tricuris muris infection in mice model, explained that oral feeding for alive L. rhamnosus potentially stimulated larval expulsion in Trichuris muris resistant C57BL/6 mice (34). A suspension of Lactobacillus acidohilus, L. delbruckii revealed potential leverage against canine ancylostomiasis (16). Researchers observed that $L$. casei has anthelminthic $75-100 \%$ prophylactic effect, and Lactobacillus plantarum P164 (17) revealed 90\% protection against $T$. spiralis, ensured that these strains are safe as protective and curative probiotics $(17,23,35,36)$, A suspension for different probiotics revealed an increased worthy preservation $90 \%$ against Anchylostoma caninum infection in dogs (16), otherwise, Bifidobacterium animalis $04450 B$ dose $9 * 10^{2}$ CFU showed less protection 33\% decrease of adult worms and $21 \%$ decrease of egg production Strongyloids venesuelensis infection in mice (37). First of all, we used orally administration with probiotic bacteria in experimental animals, but we didn't see significant or obvious results that ensure the effect of bacteria as stimulative, when compared with the control group, so we used intraperitoneally injection because larval stages (hydatid cysts) are extraintestinal, so that the effect of intraperitoneal injection was very effectively obvious than oral administration. When we compared our study with others, we saw that little studies only used the intraperitoneal injection with bacteria like Babesia, plasmodium (protozoa) (13). Differences in the effect of probiotics strains, may be due the variable study design, 
experimental animals, dependent doses, and manner of inoculation (14).

\section{Conclusion}

It may well be concluded that acidophilus plus probiotics possess have an obvious stimulative and curative effect against infection with secondary hydatid disease in mice, and may be applied as an alternative strategy against different parasitic infection.

\section{Acknowledgement}

We would like to thank Dr. Rabie Hazem Mohammed (Department of Biology, Education College for Pure Science) for providing us with the probiotic bacteria acidophilus plus from United Kingdom.

\section{References}

1. Mihmanli M, Idiz UO, Kaya C, Demir U, Bostanci O, Omeroglu S, Bozkurt E. Current status of diagnosis and treatment of hepatic $\begin{array}{llll}\text { echinococcosis. World J Hepatol. 2016:8(28):78. } & \text { J }\end{array}$ doi: 10.4254/wjh.v8.i28.1169

2. Possenti A, Manzano R, Sanchez C, Boufana B, La Torre G, Siles M, Casulli A. Potential risk factors associated with human cystic echinococcosis: Systematic review and meta-analysis. PLOS Trop Dis. 2016:10(11):1-15. doi: 10.1371/journal.pntd.0005114.

3. Chen X, Zhang R, Wen H. Experimental nanoplus ablation of multiple membrane parasite on ex vivo hydatid cyst. Bio Med Res Inter. 2018:1-9. doi: 10.1155/2018/8497283.

4. Al-Mahmood S.S., Farhan A.M., Daoud Z.S. and Hamed O.S. Pathological study of liver lesions in cattle slaughtered at Kirkuk province abattoir. I.J.V.S. 2017: 31(1): 7-16. http://dx.doi.org/10.33899/ijvs.2018.126713.

5. Matallah F., Khleaiphia W, Lamari S. and Matallah S. Gastrointestinal helminth parasites of dogs in rural areas of the north east of Algeria. I.J.V.S. 2018: 32(1): 93-98. http://dx.doi.org/10.33899/ ijvs.2018.153829.

6. Cucher MA, Macchiaroli N, Baldi G, Camicia F, Prada L, Maldonado L, Avila HG, Fox A, Gutiérrez A, Negro P, López R, Jensen O, Rosenzvit M, Kamenetzky L. Cystic echinococcosis in south America: Systematic review of species and genotype of Echinococcus granulosus sensu lato in human and natural domestic hosts. Trop Med Inter Heal. 2016:21(2):166-175. doi: 10.1111/tmi.12647.

7. Romig T, Ebi D, Wasserman M. Taxonomy and molecular epidemiology of Echinococcus granulosus. Vet Parasitol. 2015: 213:76-84. doi: 10.1016/j.vetpar.2015.07.035.

8. Vuitton DA, Azizi A, Richou C, Vuitton L, Blagosklonov O, elabrousse E, Mantion GA, Bresson S. Current interventional strategy for the treatment of hepatic alveolar echinococcosis. Expert Rev Anti Infect Therap. 2016:19(12):801-805. doi: 10.1080/14787210.2016.1240030.

9. Moazeni M, Alipour M. Echinococcus granulosus: In vitro effectiveness of worm water on protoscoleces. Parasitol. 2011:127:1417. doi: $10.1016 /$ j.exppara.2010.06.021.

10. Hill C, Guamer F, Reid GJ, Gibson GR, Merenstein DJ, Pot B, Morelli L, Canani RB, Flint HJ, Salminen S, Calder PC, Sanders ME. Expert consensus document: The international scientific association for probiotics and prebiotics consensus statement on the scope and appropriate use of the learn probiotic. Nat Rev Gastroenterol Hepatol. 2014:11(8):506-514. doi: 10.1038/nrgastro.2014.66.
11. Butel MJ. Probiotics gut microbiota and health. Med Maladies Infect. 2014:44(1):1-8. doi: 10.1016/j.medmal.2013.10.002.

12. Shida K, Nomoto K. Probiotics as efficient immunopotentiators: Translational role in cancer prevention. Indian $\mathrm{J}$ Med Res. 2013:138(5):808. PMCID: PMC3928711.

13. Bautista CR, Gomez MB, Aguilar BR, Ixta O, Martinezem F, Mosqued I. The treatment of mice with Lactobacillus casei induces protection against Babesia microti infection. Parasitol Res. 2005:97(6):472-477. doi: 10.1007/s00436-005-1475-7

14. Reda AA. Probiotics the control of helminth zoonosis. J Vet Med. 2018;9:1-10. doi: 10.1155/2018/4178986

15. Torgerson PR, Macherson CNI. The socioeconomic burden of parasitic zoonosis: global trends. Vet Parasitol. 2011:182(1):79-95.

16. Coelho MDG, Coelho FADS, Mancilha IMD. Probiotic Therapy: A promising strategy for the control of canine hookworm. J Parasitol Res. 2013;6:1-8. doi: 10.1155/2013/430413

17. Temsahy MME, Ibrahim IR, Mossallam SE, Mahrose H, Bary AA, Salam SAA. Evaluation of newly isolated probiotics in the protection against experimental intestinal trichinellosis. Vet Parasitol. 2015:214(3-4):303-314. doi: 10.1016/j.vetpar.2015.08.029.

18. Smyth JD, Barrett NJ. Procedure for testing the viability of human hydatid cyst following surgical removal especially after chemotherapy. Trans Roy Soc Trop Med Hyg. 1980;74:649-652. doi: 10.1016/0035-9203(80)90157-1.

19. Wangoo A, Ganguly NK, Mahgain RC. Phagocytic activity of monocytes in murine model of Echinococcus granulosus of human origin. J Med Res. 1989:89:40-42. PMID: 2914730.

20. Goyal N, Tiwari RP, Shukla G. Lactobacillus rhamnosus GG as an effective probiotic for murine giardiasis. Inter Perspect Infect Dis. 2011;4:8. doi: 10.1155/2011/795219

21. Al-Zubaidy KMD, Al-Falahy MDH. Principles and procedures of statistics and experimental design. ${ }^{\text {st }}$ ed. Duhok: University of Duhok printing Press; 2016. 395 p.

22. Bajagai YS, Klieve AV, Dart PJ, Bryden WI. Probiotics in animal nutrition production, impact and regulation. Anim Prod Healt. 2016;9:1-3. ISBN 978-92-5-109333-7.

23. Dovorznakova E, Buckova B, Hurnikova V, Laukova A. Effect of probiotic bacteria on phagocytosis and respiratory burst activity of blood polymorphonuclear leukocytes (PMNL) in mice infected with Trichnella spiralis. Vet Parasitol. 2016:231:69-76. doi: 10.1016/j.vetpar.2016.07.004.

24. DeL VF, Sparo MD, Sidoti A, Santin M, Basualdo A, Cordoba MA. Effect of Enterococcus faecalis CECT7121 on Cryptosporidium parvum infection in mice. Parasitol Res. 2016:115(8):3239-3244. doi: 10.1007/s00436-016-5087-1.

25. Choido PG, Sparo MD, Pezzani BC, Minvielle MC, Bassualdo JA. In vitro and in vivo effect of Enterococcus faecalis CECT7121 on Toxocara canis. Mem Instit Oswaldo Cruz. 2010:105(5):615-620. https://doi.org/10.1590/S0074-02762010000500003.

26. Holm JB, Sorobetea D, Killerich P. Chronic Trichuris muris infection decrease diversity of the intestinal microbiota and concomitantly increases abundance of Lactobacilli. PLOS One. 2015:10(5) https://doi.org/10.1371/journal.pone.0125495

27. De SCJ, Verhoeven TL, Desair J, Marchal K, Venderleyden J, Nagy I. Strong antimicrobial activity of Lactobacillus rhamnosus GG against Salmonella typhimurium due to accumulation of lactic acid. FEMS Microbiol lett. 2006:259(1):89-96. https://doi.org/10.1111/j.15746968.2006.00250.x

28. Berilli F, Di Cavallero S, Amelio DS. Interactions between parasite and microbial communities in the human gut. Frontiers Cellul Infect Microbiol. 2012:259(1):89-96. https://doi.org/10.3389/fcimb. 2012.00141

29. Mohamed AH, Osman GY, Zowail MEM, El-Esawy HMI. Effect of Lactobacillus sporogenes (probiotic) on certain parasitology and molecular aspects in Schistosoma mansoni infected mice. J Parasit Dis. 2016:40(3):823-832. doi: 10.1007/s12639-014-0586-4. 
30. Zowail MEM, Osman GY, Mohamed AH, El-Esawy HMI. Protective role of Lactobacillus sporpgenes (probiotic) on chromosomal aberrations and DNA fragmentation in Schistosoma mansoni infected mice. Egy J Exp Biol. 2012:8:121-130.

31. Santos MJ, Vasconcelose J, De Souza JR, Coutinho DME, Montengro $\mathrm{SM}$, Ximemes AE. The effect of Zymomonas mobilis culture on experimental Schistosoma mansoni infection. J Brazilian Soc Trop Med. 2004:37(6):502-504. https://doi.org/10.1590/s003786822004000600015.

32. Abdel-Salam AM, Ammar N, Abdel AZ. Effectiveness of probiotic labneh supplemented with garlic or onion oil against Schistosoma mansoni in infected mice. Inter J Dairy Sci. 2008:3(2):97-104. http://dx.doi.org/10.3923/ijds.

33. Basualdo J, Sparo M, Choido P, Ciarmela M, Minvielle M. Oral treatment with a potential probiotic (Enterococcus faecalis CECT7121) appears to reduce the parasite burden of mice infected with Toxocara canis. Anna Trop Med Parasitol. 2007:101(6):559-562. https://doi.org/10.1179/136485907x193824.
34. McClemens J, Kim J, Wang H. Lactobacillus rhamnosus ingestion promotes innate host defense in an enteric parasitic infection. Clin Vaccine Immunol. 2013:20(6):818-826. https://doi.org/10.1128/ cvi.00047-13

35. Martninez F, Fuentes BE, Bautista CR. The intraperitoneal inoculation of lactobacillus casei in mice induces total protection against Trichinella spiralis infection at low challenge doses. Parasitol Res. 2011:109(6):1609-1617. https://doi:10.1007/s00436-011-2432-2

36. Martninez F, Santiago R, Bautista CR. Effect of Lactobacillus casei Shirota strain intraperitoneal administration in CD1 mice on the establishment of Trichenilla spiralles adult worms and IgA anti $\mathrm{T}$. spiralis production. Vet Parasitol. 2009:162(1-2):171-175. https://doi.org/10.1016/j.vetpar.2009.02.010

37. Oliveria CG, David EB, Ribiero C. Effect of Biofidobacterium animalis on mice infected with Strongyloides venezulensis. Rev Instit Med Trop de São Paulo. 2014:56(2):105-109. https://doi.org/10.1590/s0036-46652014000200003. 